\begin{tabular}{c}
\hline TÜRK \\
TARIM ve DOĞA BILIMLERI \\
DERGISi \\
\hline \hline
\end{tabular}

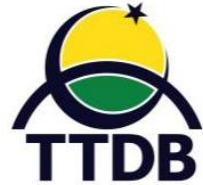

www.dergipark.gov.tr/turkjans

Araştırma Makalesi
TURKISH

JOURNAL Of AGRICULTURAL and NATURAL SCIENCES

\title{
Kapalı Sistem ve Serbest Dolaşımlı Sistemlerde Yetiştirilen Beyaz Hindilerin Besi Performansları Bakımından Karşılaştırılması
}

\author{
Hakan iNCi \\ Bingöl Üniversitesi, Ziraat Fakültesi, Zootekni Bölümü, Bingöl, Türkiye \\ Sorumlu yazar: hakaninci2565@hotmail.com
}

Geliş Tarihi: 26.02.2020 Düzeltme Geliş Tarihi: 19.03.2020 Kabul Tarihi: 20.03.2020

\begin{abstract}
Özet
$\mathrm{Bu}$ çalışma, kapalı ve serbest dolaşımlı sistemlerde yetiştirilen beyaz hindilerin canlı ağırlık performansları ve yemden yararlanmalarının belirlenmesi amacıyla yürütülmüştür. Denemede günlük yaşta toplam 90 adet hindi palazı kapalı sistem (K), \%50 yem + mera (K1) ve Mera (K2) gruplarına 3 tekerrürlü olacak şekilde şansa bağlı olarak dağıtılmıştır. K1, K2 ve K3 gruplarının 17. hafta sonundaki canlı ağırlıkları erkek + dişi karışık (ED) olarak sırasıyla; $11000 \mathrm{~g}, 9511 \mathrm{~g}$ ve $7727 \mathrm{~g}$ olarak bulunmuştur $(\mathrm{P}<0.01)$. K1 ve K2 grupları hayvan başına 17. haftanın sonunda sırasıyla; $26.15 \mathrm{~kg}$ ve $15.24 \mathrm{~kg}$ yem tüketmiştir $(P<0.05)$. K1 ve K2 gruplarının deneme sonu yemden yararlanma oranları (YYO) sırasıyla; 2.35 ve 1.60 olarak saptanmıştır $(P<0.05)$. Sonuç olarak, hindi yetiştiriciliğinde tamamen kapalı sistemler yerine uygun mevsim ve mera koşullarında tamamen mera şartlarında veya kısmen meraya dayalı sistemlerin uygulanmasıyla büyük oranda yem tasarrufu sağlanabileceği ve daha ekonomik olabileceği söylenebilir.
\end{abstract}

Anahtar kelimeler: Yetiştirme sistemi, beyaz hindi, besi performansı, mera.

The Comparison of Fattening Performance of White Turkeys Raised in Conventional and Free Range Systems

\begin{abstract}
This study was performed to compare white turkeys raised in conventional and free range systems in terms of their fattening performance and carcass traits. Totally 90 day-old turkey poults were randomly distributed into three experimental groups; Control (K1; Conventional system) $\mathrm{K} 2$ (50\% feed + pasture) and Pasture (K3) with three replications. The live weights of turkeys at $17^{\text {th }}$ week in the K1, K2 and K3 were $11000 \mathrm{~g}$, $9511 \mathrm{~g}$, and $7727 \mathrm{~g}(\mathrm{P}<0.01)$, respectively, for male+female). K1 and K2 groups at the end of 17 weeks per animal consumed $26.15 \mathrm{~kg}$ and $15.24 \mathrm{~kg}$ of feed $\mathrm{P}<0.05)$, respectively. The FCR of the K1 and K2 groups at endof-trial were 2.35 and 1.60 , respectively $(P<0.05)$. As a result, it can be said that in appropriate season and full or partially pasture grazing conditions instead of conventional system in turkey farming could be more economical by decreasing and saving feed.
\end{abstract}

Key words: Breeding system, white turkey, fattening performance, pasture.

Giriş

Ülkemizde Cumhuriyet'le beraber planlı tarım politikalarının uygulamaya başlanması, insan beslenmesinde hayvansal gıdaların öneminin anlaşılması, hayvancılık sektörünün gelişmesinde etkili faktörler olmuştur (Tan ve Dellal 2002; Yıldırım 2004; Sipahi 2010). İnsan beslenmesinde hayvansal kökenli gıdaların önemi büyüktür.

Özellikle çocuk ve genç yaştaki nüfusun hayvansal gıdalar açısından yeterli beslenmesi, fiziksel büyüme yanında zihinsel gelişme açısından da önemlidir. Türkiye'de kişi başına düşen hayvansal protein miktarının, $A B$ ve $A B D^{\prime}$ ye göre oldukça düşük olduğu bilinmektedir. Çağımızda insan sağığını tehdit eden ve hayvansal kaynaklı gıdalarla alınan kolesterolün özellikle kırmızı et tüketiminden kaynaklanıyor olması, insanları beyaz et tüketimine yönlendirmiştir. (Cömert 2004; Anonim 2014; Hall 1996). Ülkemizde hayvansal protein kaynaklarımıza alternatif olabilecek ve endüstri haline gelmiş olan kanatlı yetiştiriciliği içinde tavuk ve özellikle hindi yetiştiriciliği protein 
açığımızın kapatılmasında önem kazanmıştır (Kırkpınar ve Mert 2004; Ekinci 2015; Küçükbayrak 2015). Hindi etinin diğer etlerin besin madde içerikleri ile karşılaştırılması Çizelge 1 de verilmiştir. Türkiye'de 1980'li yıllara kadar kesilen büyük ve küçükbaş hayvan sayısı yıllar itibariyle sürekli artış gösterirken 1980 yılından sonra kesilen hayvan sayısı giderek azalmış, büyükbaş hayvancılıkta, hayvan başına verimlilikte önemli artışlar olmuştur (Gülaç 2011). Fakat özellikle son yıllarda besi maliyetlerinin yüksekliği, Doğu ve Güneydoğu'da yaşanan problemler ve fiyatlardaki istikrarsızlıklar sektörde çok ciddi problemlere yol açmıştır. Kırmızı et sektöründe yaşanan kriz, bir taraftan et arzında sıkıntılara yol açarken diğer taraftan kırmızı et ve et mamullerinin tüketiminde yetersizlikleri ortaya çıkarmıştır (Anonim 1999a; Cömert 2004; Koyubende ve Konca 2010; Anonymous 2004).

Çizelge 1. Hindi etinin diğer etlerin besin madde içerikleri ile karşılaştırılması (100 g'da)

\begin{tabular}{lcccc}
\hline & \multicolumn{2}{c}{ Kanatlı Türü } & \multicolumn{2}{c}{ Diğer Türler } \\
\hline $\begin{array}{l}\text { Besin } \\
\text { İçeriği }\end{array}$ & Hindi Eti & Piliç Eti & $\begin{array}{c}\text { Koyun } \\
\text { Eti }\end{array}$ & Sığır Eti \\
\hline $\begin{array}{l}\text { Protein } \\
\text { (g) }\end{array}$ & 20,4 & 18,6 & 14 & 20 \\
Yağ (g) & 8 & 15,1 & 18 & 12 \\
Enerji & 160 & 215 & 228 & 194 \\
(kcal/kg) & & & & \\
\hline
\end{tabular}

Kaynak: (Anonim 2007; Eratalar 2008)

Özellikle 1990'lı yıllarda kanatlı etinin diğer hayvan türlerine göre daha ekonomik üretiliyor olması, piliç üretiminde büyük entegrasyonların kurulması ve sözleşmeli üretim modelinin gelişmesiyle yıllık \%10 düzeyinde üretim artışının sağlandığı tavukçuluk sektörü, beyaz et kaynağı olarak talep görmüştür (Anonim 1999a). Bu durumda bir ölçüde piliç eti ve son yıllarda hindi etine olan talebi arttırmıştır. Gerek hayvansal ürün mamullerini çeşitlendirmek gerekse kaliteyi yükseltmek gerekliliği açısından ülkemizde hayvansal protein açığının kapatılması için piliç etine alternatif olarak hindi eti üretimine hız verilmiştir. Kırmızı et ve beyaz et karşılaştırıldığında beyaz etin kolesterol, kalori ve yağ miktarının düşük olduğu, protein ve kalsiyum miktarının yüksek olduğu, görülmektedir (Nixey 1986; Konca 2001; Işık 2010; İnci ve ark., 2013). Bu nedenle sağlık açısından beyaz etler tercih edilmektedir. Beyaz etler içerisinde proteince ve çeşitli vitaminlerce (vitamin B1, B2, nicotinamid, pantotenik asit ve folik asit) zengin olduğu, yağsız oluşu ve yapısında çok az kolesterol bulunması nedeniyle hindi etinin sağlık açısından daha yararlı olduğu bilinmektedir (Koçak 1984; Anonim 2007; Eretalar 2008; Ekinci 2015).

Ülkemizde hindicilik, 1995'li yıllara kadar sadece geleneksel olarak mera hindiciliği tipinde olup, Tarım ve Köy İşleri Bakanlığı'na bağlı üretme istasyonlarında üretilen hindi palazlarının (Bronz ırk) yetiştiricilere dağıtılması şeklinde sürdürülmüştür. Diğer yandan, dünyada 1980'lerden sonra gelişen entegre hindi üretimi, Türkiye'de 1995 yılından sonra gelişmeye başlamış ve artan taleple birlikte piyasadaki yerini giderek sağlamlaştırmıştır (Konca 2001; Küçükbayrak 2015). Türkiye'de ilk entegre hindi yetiştiriciliği 1995 yılında Bolu'da kurulmuş olan Bolca Hindi adlı bu işletmede başlamıştır. Daha sonraki yıllarda sürekli kapasitesini arttıran bu işletme bugün Türkiye hindi eti üretiminin 1/3'ünü karşılamaktadır. Bolca hindi 1999 yılında yıllık kapasitesi 1.8 milyon civciv olan kuluçkahanesini kurmuştur. Bolca hindiyi 1997 yılında Pınar grubu izlemiştir. "Çamlı Besicilik" adı altında entansif hindi eti üretimine başlamış, sözleşmeli üretim modeli ile hızla üretimini artırmıştır. Bunun dışında, Alphindi, beyaz hindi sektörüne 1997 yılında başlamış ve sürekli büyüyerek, damızlık tesisi, kuluçkahanesi, yem fabrikası, yetiştirme kümesleri, kesimhanesi, parçalama-paketleme-şoklama ve muhafaza tesisleri ve dağıtım kanalları ile tam entegre üretim yapan bir hindi tesisi halini almıştır. Ülkemizde hindi varlığı dünyada sayılı ülkeler arasındadır. Buna karşın, entansif hindi eti üretimi son yıllarda gelişme gösterebilmiştir. Bugün ülkemizde, İstanbul, Adapazarı, Bolu, İzmir gibi merkezlerde yerleşik bulunan özel sektöre ait kuruluşlar üretimde etkindir. Entegre üretim yapan bu firmalarda orta boy ve büyük boy beyaz hindiler et üretimi amacıyla yetiştirilmektedir (Anonim 2006; Eretalar 2008). Modern yetiştirme tekniklerinin hızla uygulanmaya başlandığı hayvancılıkta, modern besleme yöntemlerinin uygulamaya aktarıışı da aynı hızla yapılmaktadır. Bu yöntemin uygulanışı ülkenin veya bölgenin iklim ve toprak yapısına bağı olarak değişim göstermektedir. Bu nedenle değişik ülke veya bölgelerdeki çiftçiler, hayvanların beslenmesinde ellerindeki imkânlara uygun yem ve yem katkı maddeleri kullanmaktadır (İnci vd 2013). Son yıllarda ülkemizin yem kaynaklarına ithalat yoluyla ödediği yüksek düzeydeki döviz sebebiyle ucuz ve doğrudan insan beslenmesinde kullanılmayan yem kaynaklarının bulunmasına yönelik çalışmalar giderek ağırlık kazanmıştır (Blake 1993). Diğer hayvan türlerinde olduğu gibi hindilerde de masrafların büyük çoğunluğunu yem giderleri oluşturmaktadır. Bu yüzden hindilerin dengeli beslenmesinde hangi yemin ne kadar ve nasıl verileceğinin iyi bilinmesi gerekir (Özkan ve Ergül 
1974; Sipahi 2010). Yem giderlerinin yüksek olması nedeniyle son yıllarda tamamen kapalı olarak yapılan yetiştirme sistemlerine alternatif olarak mera hindiciliği ya da otlatmaya dayalı sistemler geliştirilmeye başlanmıştır. Mera hindiciliğin de hayvanlar çok kısa bir süre kümeste büyütüldükten sonra meraya çıkarıldıkları için yem masraflarından büyük bir tasarruf sağlanmaktadır. Hayvanlar merada böcekler ve bitkilerin değişik kısımları ile beslendikleri için gerekli olan enerji ve protein büyük bir oranda karşılanabilmektedir. Hayvanların merada ihtiyacı olan enerji ve proteini karşılamalarında meranın kalitesinin de büyük rolü vardır (Anonim 2006; Anonim 2004). Bu araştırma, Beyaz hindilerin entansif ve meraya dayalı sistemlerde yetiştirilerek büyüme, gelişme ve özelliklerinin karşılaştırılması amacıyla yapılmıştır.

\section{Materyal ve Metot}

Araştırmanın hayvan materyalini ticari bir işletmeden satın alınan Beyaz hindilere (Big-6) ait yumurtalardan kuluçka yoluyla elde edilen 90 adet hindi palazı oluşturmuştur. Döllü olarak temin edilen hindi yumurtaları Bingöl Üniversitesi Ziraat Fakültesi Zootekni Bölümüne ait kanatlı ünitesinde bulunan kuluçka makinesine yüklenmiş ve bu yumurtalardan elde edilen bir günlük palazlar denemeye alınmıştır. Hindilere verilen farklı dönemlerdeki yemler kuru madde, enerji ve diğer besin maddeleri bakımından hindilerin yaklaşık ihtiyaçlarını karşılayabilecek şekilde düzenlenmiştir. Deneme gruplarının yem karmaları, yem hammaddelerinin ham besin maddesi analiz sonuçlarına göre ve hindilerin besin maddesi gereksinimleri NRC (1983) değerleri dikkate alınarak hazırlanmıştır. Hindiler, 0-8 haftalar arasında \%26-28 ham protein ve 2800$2900 \mathrm{kcal} / \mathrm{kg} \mathrm{ME}$ içeren başlatma yemi, 9-14 haftalar arasında \%20-23 ham protein ve 2900$3000 \mathrm{kcal} / \mathrm{kg} \mathrm{ME}$ içeren büyütme yemi, 15-17 haftalar arasında ise $\% 20-23$ ham protein ve 3000 $3200 \mathrm{kcal} / \mathrm{kg}$ ME içeren yemle beslenmişlerdir. \%50 yem + mera ve mera gruplarındaki hindilerin yararlandığı meranın kompozisyonu yonca, çim, korunga, fiğ, buğday ve arpa bitkilerinden oluşturulmuştur. Sezon süresince meradan alınarak besin madde analizleri yapılan yeşil ve kuru çayır otlarının besin değerleri Çizelge 2'de verilmiştir.

Çizelge 2. Mera kompozisyonun besin madde içerikleri

\begin{tabular}{cccccc}
\hline $\begin{array}{c}H . \\
\begin{array}{c}\text { Protein } \\
(\%)\end{array}\end{array}$ & $\begin{array}{c}\text { Ham } \\
\text { Selüloz } \\
(\%)\end{array}$ & $\begin{array}{c}\text { Ham } \\
\text { Yağ } \\
(\%)\end{array}$ & $\begin{array}{c}\text { Ham } \\
\text { Kül } \\
(\%)\end{array}$ & $\begin{array}{c}\text { Kuru } \\
\text { Madde } \\
(\%)\end{array}$ & $\begin{array}{c}\text { M. Enerji } \\
(\mathrm{kcal} / \mathrm{kg})\end{array}$ \\
\hline 14,85 & 31,5 & 2,4 & 9,6 & 87 & 1900 \\
\hline \multicolumn{6}{c}{ Çalışmada, 90} \\
adet hindi palazı 3 gruba
\end{tabular}

(kapalı sistem, \%50 yem + mera ve mera) ayrılmış ve her grupta 30'ar hindi olacak şekilde 3 tekerrürlü olarak planlanmıştır.

Hindiler ilk haftadan sonra gruplara ayrılarak, 1. grup tamamen içerde ve entansif şartlarda, 2. grup çıkımdan sekizinci haftanın sonuna kadar entansif şartlarda yetiştirilmiştir. Daha sonra tamamen dışarda yetiştirilmiş ve mera döneminde ilave olarak 1 . grubun tükettiği yemin $\% 50$ 'si verilmiştir, 3. grup ise, çıkımdan sekizinci hafta sonuna kadar içeride entansif şartlara göre yetiştirilmiş ve sekizinci haftadan sonra tamamen dışarda ve mera şartlarında beslenmiş ve ek yem verilmemiştir. Denemede kullanılan rasyonların kompozisyonu ve besin madde içerikleri Çizelge 3 de verilmiştir.

Çizelge 3. Denemede kullanılan rasyonların kompozisyonu ve besin madde içerikleri

\begin{tabular}{lccc}
\hline Besin Maddeleri & $0-8$ hafta & $\begin{array}{c}9-14 \\
\text { hafta }\end{array}$ & 15-17 hafta \\
\hline Ham Protein (\%) & $26-28$ & $20-23$ & $16-19$ \\
Ham Selüloz (\%) & $6-7$ & 8 & $6-7$ \\
Nem (\%) & 12 & 12 & 12 \\
Ham Kül (\%) & 8 & 8 & 8 \\
Kalsiyum (\%) & $1,0-1,5$ & $0,8-1,2$ & $1,0-1,5$ \\
Fosfor (\%) & 0,8 & 0,65 & 0,8 \\
Lizin (\%) & $1,3-1,6$ & 0,72 & 1,3 \\
Metiyonin (\%) & $0,4-0,6$ & 0,19 & 0,38 \\
Tuz (\%) & 0,35 & 0,35 & 0,35 \\
ME (kcal/kg) & $2800-$ & $3000-$ & 3200 \\
\hline
\end{tabular}

Deneme Haziran ve Ekim döneminde yürütülmüştür. Deneme süresince tamamen entansif şartlarda yetiştirilen hindiler, tel örgülerle çevrili ve altlıklı yer bölmelerinde barındırılmışlardır (Çizelge 4). Mera grupları ise ilk sekiz hafta boyunca yine aynı kümeste barındırılmış ve daha sonra meraya çıkarılmışlardır. Yer bölmelerinde hayvanlara sağlanan yerleşim sıklığı hindilerin yaşına ve besi süresine bakılarak belirlenmiştir.

Çizelge 4. Yer bölmelerinde barındırılan hindilere uygulanan yerleşim sıklığı

\begin{tabular}{lcccccc}
\hline Yaş (hafta) & 1 & 2 & $4-8$ & $8-12$ & $12-16$ & $16-17$ \\
\hline $\begin{array}{l}\text { Sayı } \\
\text { (adet } / \mathrm{m}^{2} \text { ) }\end{array}$ & 40 & 30 & 10 & 5 & 4 & 3 \\
\hline
\end{tabular}

Deneme odasının aydınlatması için, ikişer adet 60 Watt'lık ampul, ısıtma için ise otomatik olarak ısıya ayarlanabilen elektrikli soba kullanılmıştır. Oda üç eşit bölmeye ayrılmış ve her bölmede $8 \mathrm{~cm}$ kalınlıkta odun talaşı ve saman karışımı altlık kullanılmıştır. Bölmeler içerisine özel kavanoz tipi suluk ve yem kaybını önlemek amacıyla da üzerine tel ızgara bulunan plastik yemlikler yerleştirilmiştir. Barınaklarda hayvanların 
sağlığı açısından gerekli hijyenik tedbirler alınmıştır. Deneme hayvanlarının canlı ağılıkları, yem tüketimleri, iki haftalık periyotlarla ve sabah aynı saatte (10:00) yapılan tartımlarla tespit edilmiştir. Askılı yemlik ve sulukların kullanıldığı kümeste yem ve su, hayvanlara ad libitum (serbest) olarak verilmiştir. Kuluçkadan yeni çıkmış olan palazların 1. ve 2. haftalarda yapılan tartımlarında $0,01 \mathrm{~g}$ hassasiyetli terazi kullanılmıştır. Daha sonraki haftalarda yapılan tartımlarda ise $2 \mathrm{~g}$ hassasiyetli dijital kantar kullanılmıştır. Kümes içerisinde ilk 8 haftalık periyot süresince gün ışığına ek olarak yapay aydınlatma ile günde 24 saat aydınlatma uygulanmıştır. $\% 50$ yem + mera ve mera gruplarının meraya çıkarıldıklarından 8. haftadan sonra) itibaren aydınlatma süresi gün ışığına bağlı olmuştur. İncelenen özelliklere ait veriler SAS (1988) istatistik paket programında analiz edilmiştir. Üç grubun arasındaki farklar hesaplanırken $\mathrm{F}$ testi, iki grubun arasındaki farklar için T testi uygulanmış olup, ortalamalar arasındaki farklılıkların önemlilik derecelerinin tespitinde ise Duncan testi kullanılmıştır.

\section{Bulgular ve Tartışma}

\section{Canlı Ağırlık}

Palazların kuluçkadan çıkış ağırlıkları bakımından elde edilen ortalama değerler, kapalı sistem, \%50 yem + mera ve mera gruplarında erkek

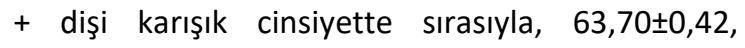
$63,90 \pm 0,42$ ve $64,01 \pm 0,42 \mathrm{~g}$ olarak saptanmıştır. Muamele gruplarına ait ortalamalar arasındaki farklılıklar önemsiz bulunmuştur. İkinci haftadaki canlı ağırlık ortalamaları, kapalı sistem, \%50 yem + mera ve mera gruplarında erkekler için sırasıyla; $234,71 \pm 15,01,250,11 \pm 13,24$ ve $262,18 \pm 11$ g olarak bulunmuş ve gruplara ait ortalamalar arasındaki farklılıklar önemsiz olmuştur. Canlı ağılık ortalamaları dişiler için ise sırasıyla; $228,08 \pm 8,50$, $230,61 \pm 8,90$ ve $241,31 \pm 9,36$ g olarak bulunmuştur. Dişiler bakımından ortalamalar arasındaki farklılıklar önemsiz bulunmuştur. Erkek + dişi karışık cinsiyette ortalama canlı ağırlıklar yukarıdaki sirayla, $233,98 \pm 7,73,239,72 \pm 7,50$ ve $251,14 \pm 7,42$ g olarak saptanmıştır. Muamele gruplarına ait ortalamalar arasındaki farklılıklar önemsiz bulunmuştur. Altıncı haftada, kapalı sistem, \%50 yem + mera ve mera gruplarında erkek hindilerin canlı ağırlık ortalamaları sırasıyla; 1685 $\pm 95,91$, $1671,22 \pm 84,58$ ve $1768,27 \pm 76,51 \mathrm{~g}$ olarak saptanmış ve gruplara ait ortalamalar arasındaki farklılıklar önemsiz bulunmuştur (Şekil 1). Dişilerin canlı ağırlık ortalamaları ise sırasıyla, 1492 $\pm 48,53$, $1479,80 \pm 50,79$ ve $1453,05 \pm 53,40$ g olarak bulunmuş ve gruplara ait ortalamalar arasındaki farklılıklar önemsiz bulunmuştur (Şekil 2). Erkek + dişi karışık cinsiyette hindilerin canlı ağırlık ortalamaları sırasıyla, 1600,54 $\pm 45,83$, $1584,86 \pm 44,79$ ve $1600,38 \pm 44,03$ g olarak saptanmıştır (Şekil 3). Muamele gruplarına ait ortalamalar arasındaki farklılıklar önemsiz bulunmuştur. Onuncu haftada farklı yetiştirme sistemlerinin hindilerin canlı ağılıkları üzerine etkileri önemli $(P<0,01)$ olmuş ve tüm cinsiyet gruplarına ait değerler farklılık arz etmiştir. Kapalı sistem, \%50 yem + mera ve mera gruplarına ait erkek hindilerin canlı ağırlık ortalamaları sırasıyla; $5249 \pm 144,75,3777,88 \pm 127,65$ ve $3448,72 \pm 115,47$ g olarak saptanmış ve gruplara ait ortalamalar arasındaki farklılıklar önemli $(P<0,01)$ bulunmuştur. Dişilerin canlı ağırlık ortalamaları ise sırasıyla; $4609,04 \pm 93,62,3358,90 \pm 97,97$ ve $2790,89 \pm 103 \mathrm{~g}$ olarak saptanmış ve gruplara ait ortalamalar arasındaki farklılıklar önemli $(P<0,01)$ bulunmuştur. Erkek + dişi karışık cinsiyette hindilerin canlı ağırlık ortalamaları sırasıla; 4910,88 $\pm 82,71$, $3598,98 \pm 80,83$ ve $3108,35 \pm 79,46 \mathrm{~g}$ olarak saptanmış ve gruplara ait ortalamalar arasındaki farklılıklar önemli $(P<0,01)$ bulunmuştur. On dördüncü haftada, kapalı sistem, $\% 50$ yem + mera ve mera gruplarında erkek hindilerin canlı ağırlık ortalamaları sırasıyla; 8186,42 $\pm 274,13$, $6955,88 \pm 241,76$ ve $5308,54 \pm 218,68 \mathrm{~g}$ olarak saptanmış ve gruplara ait ortalamalar arasındaki farklılıklar önemli $(P<0,01)$ bulunmuştur. Dişilerin canlı ağırlık ortalamaları ise sırasıyla; $7347,04 \pm 159,56, \quad 6018,30 \pm 163,50$ ve $4491,70 \pm 177,34 \mathrm{~g}$ olarak saptanmış ve gruplara ait ortalamalar arasındaki farklılıklar önemli $(P<0,01)$ bulunmuştur. Erkek + dişi karışık cinsiyette hindilerin canlı ağırlık ortalamaları sırasıyla; $7773,06 \pm 142,64$, 6473,26 $\pm 137,64$ ve $4905,25 \pm 137,42$ g olarak saptanmış olup, muamele gruplarına ait ortalamalar arasındaki farklılıklar önemli $(P<0,01)$ bulunmuştur. On yedinci haftada muamele gruplarına ait hindilerin canlı ağırlık ortalamaları yetiştirme sisteminden etkilenmiştir. Canlı ağırlık ortalamaları bakımından en yüksek değer kapalı sistem grubunda, en düşük değer ise mera grubunda elde edilmiştir. Kapalı sistem, \%50 yem + mera ve mera gruplarında erkek hindilerin canlı ağırlık ortalamaları sırasıyla; $12285,71 \pm 281,63, \quad 10127,22 \pm 248,38$ ve $8438,18 \pm 224,66$ g olarak saptanmış ve gruplara ait ortalamalar arasındaki farklılıklar önemli $(P<0,01)$ bulunmuştur. Dişilerin canlı ağırlık ortalamaları sırasıyla; $10164,20 \pm 206,37,8797,10 \pm 211,73$ ve $6985,29 \pm 223,84 \mathrm{~g}$ olarak saptanmış ve gruplara ait ortalamalar arasındaki farklılıklar önemli $(P<0,01)$ bulunmuştur. Erkek + dişi karışık cinsiyette hindilerin canlı ağırlık ortalamaları sırasıyla; $11100,39 \pm 175,55, \quad 9511,08 \pm 169,39$ ve $7727,93 \pm 166,81 \mathrm{~g}$ olarak saptanmıştır. Muamele 
gruplarına ait ortalamalar arasındaki farklılıklar önemli $(P<0,01)$ bulunmuştur (Çizelge 5$)$.

Çizelge 5. Deneme gruplarına ait hindilerin farklı haftalardaki canlı ağırlık ortalamaları (g) ve standart hataları $(\mathrm{X} \pm \mathrm{Sx})$

\begin{tabular}{|c|c|c|c|c|c|c|c|c|}
\hline Hafta & Cins & $\begin{array}{l}\text { Kapalı Sistem } \\
\quad(X \pm S x)\end{array}$ & $\mathrm{n}$ & $\begin{array}{c}\text { \%50 yem+mera } \\
(X \pm S x)\end{array}$ & $\mathrm{n}$ & $\begin{array}{l}\text { Mera } \\
(\mathrm{X} \pm \mathrm{Sx})\end{array}$ & $\mathrm{n}$ & $\mathrm{P}$ \\
\hline \multirow[t]{2}{*}{0} & $\mathrm{~K}$ & $63,70 \pm 0,42 a$ & 30 & $63,90 \pm 0,42 a$ & 30 & $64,01 \pm 0,42 a$ & 30 & Önz \\
\hline & $\mathrm{E}$ & $234,71 \pm 15,01 a$ & 10 & $250,11 \pm 13,24 a$ & 10 & $262,18 \pm 11,97 a$ & 10 & Önz \\
\hline \multirow{2}{*}{2} & D & $228,08 \pm 8,50 a$ & 20 & $230,61 \pm 8,90 a$ & 20 & $241,31 \pm 9,36 a$ & 20 & Önz \\
\hline & $\mathrm{K}$ & $233,98 \pm 7,73 a$ & 30 & $239,72 \pm 7,50 a$ & 30 & $251,14 \pm 7,42 a$ & 30 & Önz \\
\hline \multirow[b]{3}{*}{4} & $E$ & $687,14 \pm 44,94 a$ & 10 & $731,14 \pm 39,64 a$ & 10 & $754,63 \pm 35,85 a$ & 10 & Önz \\
\hline & D & $634,86 \pm 23,06 a$ & 20 & $662,19 \pm 24,13 a$ & 20 & $662,15 \pm 25,37 a$ & 20 & Önz \\
\hline & K & $666,55 \pm 21,58 a$ & 30 & $697,61 \pm 21,09 a$ & 30 & $705,81 \pm 20,73 a$ & 30 & Önz \\
\hline \multirow[b]{3}{*}{6} & E & $1685 \pm 95,91 a$ & 10 & $1671,22 \pm 84,58 a$ & 10 & $1768,27 \pm 76,51 a$ & 10 & Önz \\
\hline & D & $1492 \pm 48,53 a$ & 20 & $1479,80 \pm 50,79 a$ & 20 & $1453,05 \pm 53,40 a$ & 20 & Önz \\
\hline & K & $1600,54 \pm 45,83 a$ & 30 & $1584,86 \pm 44,79 a$ & 30 & $1600,38 \pm 44,03 a$ & 30 & Önz \\
\hline \multirow[b]{3}{*}{8} & $\mathrm{E}$ & $3188,14 \pm 148,13 a$ & 10 & $3173,77 \pm 130,64 a$ & 10 & $3460,72 \pm 118,17 a$ & 10 & Önz \\
\hline & D & $2852,95 \pm 68,58 a$ & 20 & $2724,19 \pm 71,77 a$ & 20 & $2833,68 \pm 75,46 a$ & 20 & Önz \\
\hline & K & $3059,96 \pm 67,17 a$ & 30 & $2955,66 \pm 65,65 a$ & 30 & $3127,99 \pm 64,53 a$ & 30 & Önz \\
\hline \multirow[b]{3}{*}{10} & $\mathrm{E}$ & $5249 \pm 144,75 a$ & 10 & $3777,88 \pm 127,65 b$ & 10 & $3448,72 \pm 115,47 b c$ & 10 & $* *$ \\
\hline & D & $4609,04 \pm 93,62 a$ & 20 & $3358,90 \pm 97,97 b$ & 20 & $2790,89 \pm 103 c$ & 20 & $* *$ \\
\hline & K & $4910,88 \pm 82,71 a$ & 30 & $3598,98 \pm 80,83 b$ & 30 & $3108,35 \pm 79,46 c$ & 30 & $* *$ \\
\hline \multirow[b]{3}{*}{12} & $E$ & $6920,57 \pm 196,37 a$ & 10 & $5402,22 \pm 173,18 b$ & 10 & $4405,72 \pm 156,65 c$ & 10 & $* *$ \\
\hline & D & $5912,78 \pm 126,43 a$ & 20 & $4751 \pm 132,31 b$ & 20 & $3757,94 \pm 147,06 c$ & 18 & $* *$ \\
\hline & $\mathrm{K}$ & $6349,07 \pm 111,94 a$ & 30 & $5097,22 \pm 109,36 b$ & 30 & $4093,24 \pm 110,63 c$ & 28 & $* *$ \\
\hline \multirow[b]{3}{*}{14} & $\mathrm{E}$ & $8186,42 \pm 274,13 a$ & 10 & $6955,88 \pm 241,76 b$ & 10 & $5308,54 \pm 218,68 c$ & 10 & $* *$ \\
\hline & D & $7347,04 \pm 159,56 a$ & 18 & $6018,30 \pm 163,50 b$ & 19 & $4491,70 \pm 177,34 c$ & 18 & $* *$ \\
\hline & K & $7773,06 \pm 142,64 a$ & 28 & $6473,26 \pm 137,64 b$ & 29 & $4905,25 \pm 137,42 c$ & 28 & $* *$ \\
\hline \multirow[b]{3}{*}{16} & $E$ & $10833,57 \pm 292,88 a$ & 10 & $8813,44 \pm 258,30 b$ & 10 & $7650,54 \pm 233,64 c$ & 10 & $* *$ \\
\hline & D & $8975 \pm 193,70 a$ & 17 & $7597,21 \pm 203,64 b$ & 18 & $6401,23 \pm 215,28 c$ & 18 & $* *$ \\
\hline & K & $9793,50 \pm 169,14 a$ & 27 & $8240,90 \pm 165,43 b$ & 28 & $7043,69 \pm 162,92 c$ & 28 & $* *$ \\
\hline \multirow[b]{3}{*}{17} & $\mathrm{E}$ & $12285,71 \pm 281,63 a$ & 10 & $10127,22 \pm 248,38 b$ & 10 & $8438,18 \pm 224,66 c$ & 10 & $* *$ \\
\hline & D & $10164,20 \pm 206,37 a$ & 17 & $8797,10 \pm 211,73 b$ & 18 & $6985,29 \pm 223,84 c$ & 18 & $* *$ \\
\hline & K & $11100,39 \pm 175,55 a$ & 27 & $9511,08 \pm 169,39 b$ & 28 & $7727,93 \pm 166,81 c$ & 28 & $* *$ \\
\hline
\end{tabular}

a,b,c: Aynı satırda farklı harfle gösterilen ortalamalar arasındaki farklılıklar önemlidir. E: Erkek, D: Dişi, K:Erkek +Dişi, n: Hayvan sayısı, Önz: Önemsiz, P: Önem düzeyi, **: $\mathrm{P}<0,01$. 


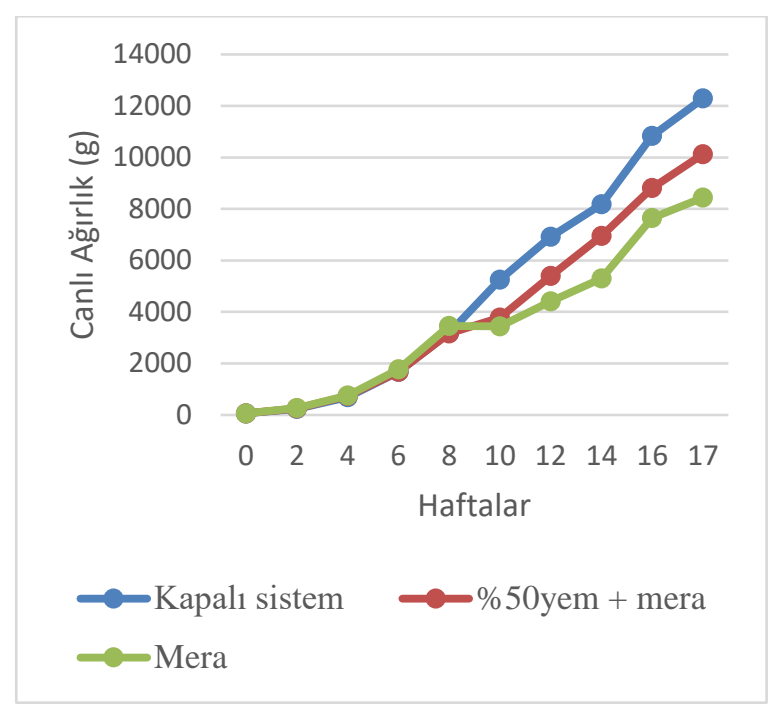

Şekil 1. Kapalı sistem, \%50 yem + mera ve mera gruplarına ait erkek hindilerin canlı ağırlık artışları

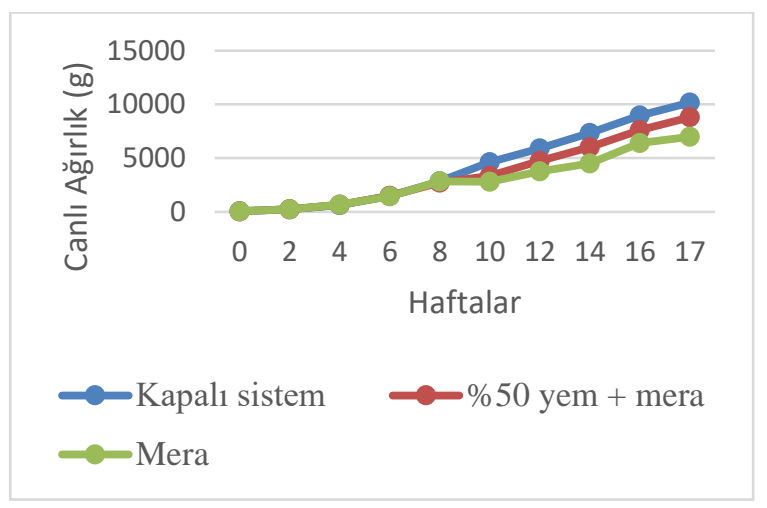

Şekil 2. Kapalı sistem, $\% 50$ yem + mera ve mera gruplarına ait dişi hindilerin canlı ağırlık artışları

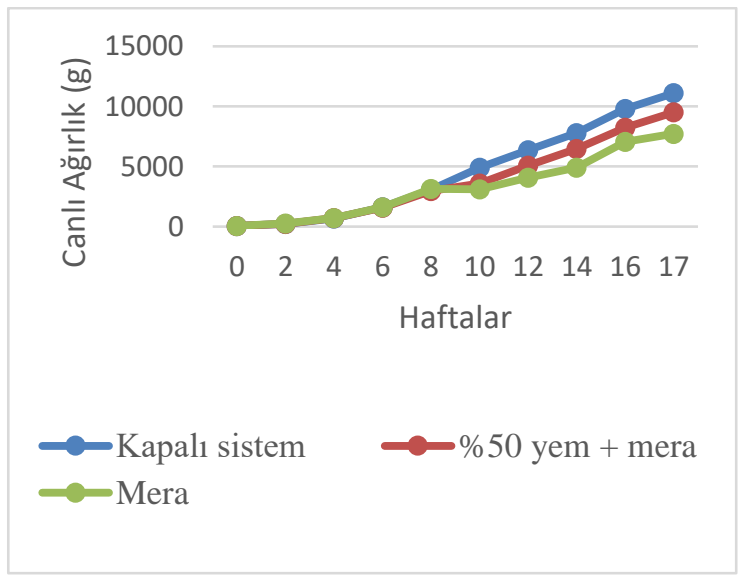

Şekil 3. Kapalı sistem, $\% 50$ yem + mera ve mera gruplarına ait erkek + dişi karışık hindilerin canlı ağırlık artışları

\section{Yem Tüketimi}

Illk 2 haftadaki yem tüketim ortalamaları, kapalı sistem grubu, \%50 yem + mera grubu ve mera grubu için sırasıyla; $0,31 \pm 0,01,0,31 \pm 0,01$ ve $0,32 \pm 0,01 \mathrm{~kg}$ olarak saptanmıştır. Yem tüketimi bakımından gruplar arasındaki farklılıklar önemsiz bulunmuştur. 0-4 haftalar arasındaki yem tüketim ortalamaları, kapalı sistem, \%50 yem + mera ve mera grupları için sırasıyla; $0,88 \pm 0,02,0,90 \pm 0,02$ ve $0,91 \pm 0,02 \mathrm{~kg}$ olarak saptanmış olup gruplar arasındaki farklııklar önemsiz bulunmuştur. 0-6 haftalık dönemde hindilerin yem tüketimleri, Kapalı sistem, \%50 yem + mera ve mera grupları için sırasıyla; $2,14 \pm 0,02,2,16 \pm 0,02$ ve $2,15 \pm 0,02 \mathrm{~kg}$ olarak saptanmıştır (Şekil 4). Elde edilen ortalamalar arasındaki farklılıklar istatistiksel olarak önemsiz bulunmuştur. 0-8 haftalar arasındaki yem tüketim ortalamaları, kapalı sistem, \%50 yem + mera ve mera grupları için sırasıyla; $4,30 \pm 0,06$, $4,30 \pm 0,06$ ve $4,35 \pm 0,06 \mathrm{~kg}$ olarak saptanmış olup muamele grupları arasındaki farklılıklar önemli bulunmamıştır. 0-10. haftalar arasındaki dönemde yetiştirme sistemi grupların yem tüketimini etkilemiştir. Yem tüketimi, kapalı sistem ve \%50 yem + mera grubunda sırasıyla; 7,87 $\pm 0,07$ ve $6,09 \pm 0,07 \mathrm{~kg}$ olarak saptanmıştır. Mera grubu ise, yalnızca merada beslendiğinden yem tüketimi olmamıştır. ilk iki grubun yem tüketimleri arasındaki farklılıklar önemli $(P<0,05)$ bulunmuştur. 0-12 haftalar arasındaki dönemde yem tüketim ortalamaları, Kapalı sistem ve \%50 yem + mera grubunda sırasıyla; $12,03 \pm 0,06$ ve $8,17 \pm 0,06 \mathrm{~kg}$ olarak saptanmıştır. Yem tüketimi açısından gruplar arasındaki farklılıklar önemli $(P<0,05)$ bulunmuştur. 0-14 haftalık periyotta grupların yem tüketim ortalamaları, kapalı sistem ve $\% 50$ yem + mera grubunda sırasıyla; $16,46 \pm 0,06$ ve $10,39 \pm 0,06 \mathrm{~kg}$ olarak saptanmış olup, muamele grupları arasındaki farklılıklar önemli $(P<0,05)$ bulunmuştur. 0-16. haftalar arasında muamele gruplarına ait yem tüketim ortalamaları, Kapalı sistem ve $\% 50$ yem + mera grubunda sırasıyla; $22,17 \pm 0,10$ ve $13,25 \pm 0,10$ kg olarak saptanmıştır. Yem tüketimi bakımından gruplar arasındaki farklılıklar önemli $(P<0,05)$ bulunmuştur. 0-17 haftalık besi periyodu süresince grupların yem tüketim ortalamaları, kapalı sistem ve $\% 50$ yem + mera grupları için sırasıyla; $26,15 \pm 0,13$ ve $15,24 \pm 0,13 \mathrm{~kg}$ olarak saptanmış, gruplar arasındaki farklılıklar önemli $(P<0,05)$ bulunmuştur (Çizelge 6). 
Çizelge 6. Farklı yetiştirme sistemlerinde barındırılan hindilerin yem tüketimleri (kg)

\begin{tabular}{|c|c|c|c|c|}
\hline Hafta & $\begin{array}{l}\text { Kapalı sistem } \\
\qquad(\mathrm{X} \pm \mathrm{Sx})\end{array}$ & $\begin{array}{c}\text { \%50 Yem+Mera } \\
(X \pm S x)\end{array}$ & $\begin{array}{l}\text { Mera } \\
(X \pm S x)\end{array}$ & $\mathrm{P}$ \\
\hline $0-2$ & $0,31 \pm 0,01 a$ & $0,31 \pm 0,01 a$ & $0,32 \pm 0,01 a$ & Önz \\
\hline $0-4$ & $0,88 \pm 0,02 a$ & $0,90 \pm 0,02 a$ & $0,91 \pm 0,02 a$ & Önz \\
\hline $0-6$ & $2,14 \pm 0,02 a$ & $2,16 \pm 0,02 a$ & $2,15 \pm 0,02 a$ & Önz \\
\hline $0-8$ & $4,30 \pm 0,06 a$ & $4,30 \pm 0,06 a$ & $4,35 \pm 0,06 a$ & Önz \\
\hline $0-10$ & $7,87 \pm 0,07 a$ & $6,09 \pm 0,06 b$ & & $*$ \\
\hline $0-12$ & $12,03 \pm 0,06 a$ & $8,17 \pm 0,06 b$ & & $*$ \\
\hline $0-14$ & $16,46 \pm 0,06 a$ & $10,39 \pm 0,06 b$ & & $*$ \\
\hline $0-16$ & $22,17 \pm 0,10 a$ & $13,25 \pm 0,10 b$ & & $*$ \\
\hline $0-17$ & $26,15 \pm 0,13 a$ & $15,24 \pm 0,13 b$ & & $*$ \\
\hline
\end{tabular}

a,b: Aynı satırda farklı harfle gösterilen ortalamalar arasındaki farklılıklar önemlidir. Önz: Önemsiz *:P<0,05, P: Önem düzeyi

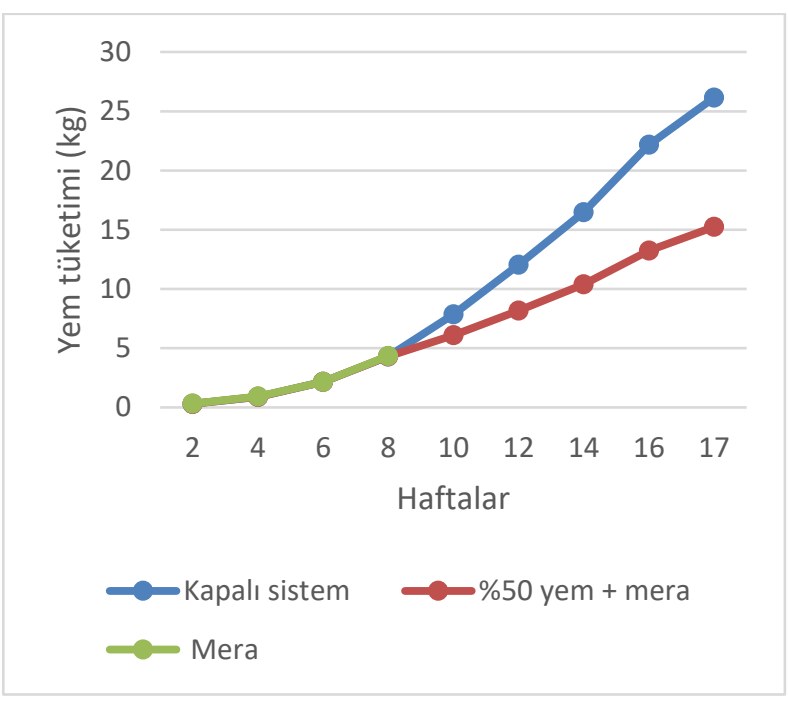

Şekil 4. Farklı yetiştirme sistemlerinde barındırılan hindilerin yem tüketimleri $(\mathrm{kg})$

\section{Yemden Yararlanma Oranı}

0-8 haftalık dönemde gruplara ait oranları, kapalı sistem, \%50 yem + mera ve mera gruplarında sırasıyla; $1,40 \pm 0,03,1,45 \pm 0,03$ ve $1,39 \pm 0,03$ olarak saptanmıştır. Elde edilen ortalamaları arasındaki farklılıklar önemsiz bulunmuştur. 0-10 haftalık periyotta ise Kapalı ve $\% 50$ yem + mera sisteminde yetiştirilen hindilere ait yemden yararlanma oranları hesaplanmıştır. Mera grubuna ek yem verilmediğinden dikkate alınmamıştır. Bu dönemdeki yemden yararlanma oranları, kapalı sistem ve \%50 yem + mera grubunda sırasıyla; $1,60 \pm 0,02$ ve $1,69 \pm 0,02$ olarak saptanmıştır. Ortalamalar arasındaki farklılıklar önemli $(P<0,05)$ bulunmuştur. 0-12 haftalık dönemde yemden yararlanma oranları, Kapalı sistem ve $\% 50$ yem + mera grubunda sırasıyla; $1,89 \pm 0,02$ ve $1,72 \pm 0,02$ olarak saptanmıştır. Gruplara ait ortalamalar arasındaki farklılıklar önemli $(P<0,05)$ bulunmuştur. 0-14 haftalık periyotta muamele gruplarına ait yemden yararlanma oranları, Kapalı sistem ve $\% 50$ yem + mera grubu için sırasıyla; $2,11 \pm 0,01$ ve $1,61 \pm 0,01$ olarak saptanmıştır. $\mathrm{Bu}$ dönemde yemden yararlanma oranı yetiştirme sisteminden önemli $(P<0,05)$ düzeyde etkilenmiş ve ortalamalar arasındaki farklılıklar istatistiksel anlamda önemli bulunmuştur. 0-16 haftalardaki sonuçlar da bir önceki dönemle benzer olmuş ve gruplara ait yemden yararlanma oranları, kapalı ve $\% 50$ yem + mera grubu için sırasıyla; $2,26 \pm 0,03$ ve $1,61 \pm 0,03$ olarak saptanmıştır. Gruplara ait ortalamalar arasındaki farklılıklar önemli $(P<0,05)$ bulunmuştur. 0-17 haftalık besi dönemi süresince grupların yemden yararlanma oranları yetiştirme sisteminden önemli $(P<0,05)$ düzeyde etkilenmiştir. Yemden yararlanma oranları, kapalı ve $\% 50$ yem + mera grubunda sırasıyla; $2,35 \pm 0,03$ ve $1,60 \pm 0,03$ olarak saptanmıştır. Muamele gruplarına ait ortalamalar arasındaki farklılıklar önemli $(P<0,05)$ bulunmuştur (Çizelge 7, Şekil 5). 
Çizelge 7. Farklı yetiştirme sistemlerinde barındırılan hindilerin yemden yararlanma oranları ( $\mathrm{kg} / \mathrm{kg}$ )

\begin{tabular}{ccccc}
\hline & Kapalı sistem $(\mathrm{X} \pm \mathrm{Sx})$ & $\begin{array}{c}\text { \%50 yem+mera } \\
(\mathrm{X} \pm \mathrm{Sx})\end{array}$ & $\begin{array}{c}\text { Mera } \\
(\mathrm{X} \pm \mathrm{Sx})\end{array}$ & $\mathrm{P}$ \\
\hline Hafta & $\mathrm{X} \pm \mathrm{Sx}$ & & $1,27 \pm 0,03 \mathrm{a}$ & Önz \\
$0-2$ & $1,32 \pm 0,03 \mathrm{a}$ & $1,29 \pm 0,03 \mathrm{a}$ & $1,28 \pm 0,03 \mathrm{a}$ & Önz \\
$0-4$ & $1,32 \pm 0,03 \mathrm{a}$ & $1,29 \pm 0,03 \mathrm{a}$ & $1,34 \pm 0,03 \mathrm{a}$ & Önz \\
$0-8$ & $1,34 \pm 0,03 \mathrm{a}$ & $1,36 \pm 0,03 \mathrm{a}$ & $1,39 \pm 0,03 \mathrm{a}$ & $*$ \\
$0-10$ & $1,40 \pm 0,03 \mathrm{a}$ & $1,45 \pm 0,03 \mathrm{a}$ & & $*$ \\
$0-12$ & $1,60 \pm 0,02 \mathrm{~b}$ & $1,69 \pm 0,02 \mathrm{a}$ & & $*$ \\
$0-14$ & $1,89 \pm 0,02 \mathrm{a}$ & $1,72 \pm 0,02 \mathrm{~b}$ & & $*$ \\
$0-16$ & $2,11 \pm 0,01 \mathrm{a}$ & $1,61 \pm 0,01 \mathrm{~b}$ & & $*$ \\
$0-17$ & $2,26 \pm 0,03 \mathrm{a}$ & $1,61 \pm 0,03 \mathrm{~b}$ & & \\
\hline
\end{tabular}

a,b: Aynı satırda farklı harfle gösterilen ortalamalar arasındaki farklılıklar önemlidir. Önz: Önemsiz, *: P<0,05, P: Önem düzeyi;

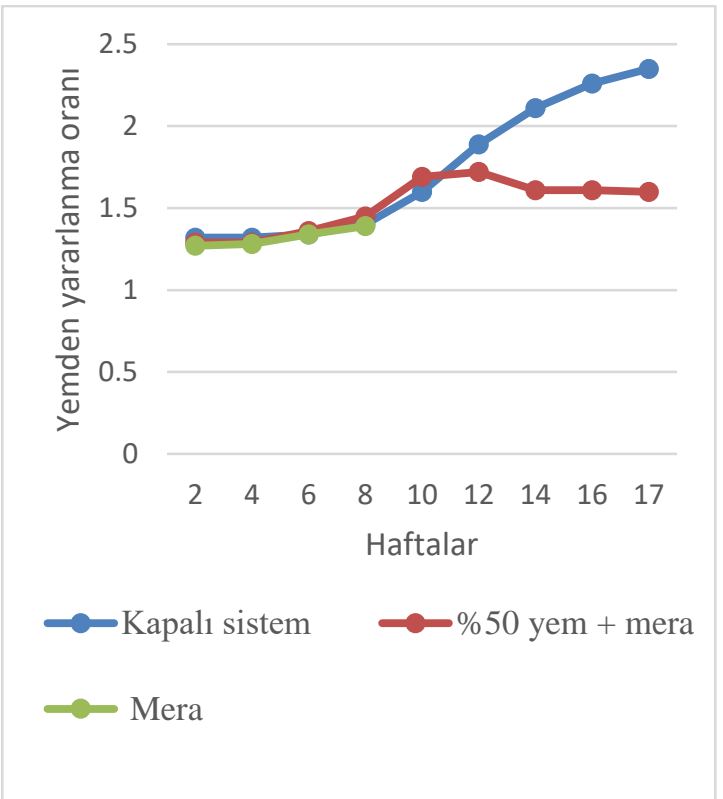

Şekil 5. Farklı yetiştirme sistemlerinde barındırılan hindilerin yemden yararlanma oranları $(\mathrm{kg} / \mathrm{kg})$

\section{Tartışma ve Sonuç}

Beyaz hindilerin besi performansı ve karkas özellikleri bakımından karşılaştırıldığı bu araştırmada, Beyaz hindiler, kapalı sistem (entansif sistem), \%50 yem + mera (yarı entansif) ve mera (ekstansif sistem) olmak üzere üç gruba ayrılarak yetiştirilmişlerdir. Illk 8 hafta sonunda muamele gruplarına ait hindilerin canlı ağılıkları karşılaştırıldığında tüm gruplarda benzer bulgular elde edilmiştir. Bunun nedeni, ilk 8 haftalık süre içerisinde tüm grupların benzer koşullarda barındırılmasıdır. 10. haftada ise, grupların canlı ağırlık ortalamaları arasında önemli $(P<0,01)$ farklılıkların olduğu gözlenmiştir. Kapalı sistem grubundaki hindilerin canlı ağırlık ortalaması diğer gruplardan daha yüksek olmuştur. En düşük canlı ağırık ortalaması merada tutulan gruptan elde edilmiştir. Ortalamalar arasındaki fark erkek, dişi ve karışık gruplarda önemli $(P<0,01)$ bulunmuştur. Bu dururumun sebebi olarak hayvanların meraya ilk defa çıkmaları ve meraya adaptasyon süresi içerisinde olmaları söylenebilir. Gruplara ait hindilerin 17. haftanın sonundaki canlı ağırlık ortalamaları, kapalı grupta Erkek + Dişi karışık $11100,39 \pm 175,55 \mathrm{~g}$, yarı entansif grupta $9511,08 \pm 169,39 \mathrm{~g}$ ve tamamen mera sartlarında beslenen mera grubunda $7727,93 \pm 166,81 \mathrm{~g}$ olarak bulunmuştur. Kapalı grubun (Erkek + Dişi ) canlı ağırlık ortalaması diğer muamele gruplarına oranla daha yüksek ve ortalamalar arasındaki farklılıklar önemli $(P<0,01)$ olmuştur. Entansif ve yarı entansif (meraya dayalı) koşullarda yetiştirilen Bronz hindilerin 16 haftalık besi periyodu sonundaki canlı ağırlık ortalamalarını entansif şartlarda barındırılan hindiler için (Erkek + Dişi) 4273,8 $\pm 95,5$ g, yarı entansif şartlarda yetiştirilenler için ise $4185 \pm 107 \mathrm{~g}$ olarak saptamış ve canlı ağırlıklara ait ortalamalar arasındaki farklılıkların önemsiz olduğunu bildirmişlerdir. Yem tüketimi bakımından 0-8 haftalık dönem sonunda kapalı sistem, \%50 yem + mera ve mera gruplarında, erkek + dişi karışık cinsiyette ortalama yem tüketimleri sırasıyla, $4,30 \pm 0,06,4,30 \pm 0,06,4,31 \pm 0,06 \mathrm{~kg}$ olarak saptanmış ve gruplar arasındaki farklılıklar önemsiz bulunmuştur. Hayvanların meraya çıkmaya başladığı 8. haftadan 17. haftaya kadar yem tüketim ortalamaları, kapalı sistem ve $\% 50$ yem + mera grubunda, erkek + dişi karışık için sırasıyla, $26,15 \pm 0,13$ ve $15,24 \pm 0,13 \mathrm{~kg}$ olarak saptanmıştır. Gruplara ait hindilerin yem tüketimleri arasındaki farklılıklar önemli $(P<0,05)$ bulunmuştur. Yemden yararlanma oranı bakımından gruplar değerlendirildiğinde, ilk sekiz hafta için kapalı sistem, \%50 yem + mera ve mera gruplarında, erkek + dişi karışık cinsiyette sırasıyla; $1,40 \pm 0,03$, $1,45 \pm 0,03$ ve $1,37 \pm 0,03$ olarak saptanmıştır. Muamele grupları arasındaki farklılıklar önemsiz bulunmuştur. Sekizinci haftadan 17. haftanın sonuna kadar yemden yararlanma oranları 
bakımından gruplar arasındaki farklılıklar önemli $(P<0,05)$ bulunmuştur. 17 haftalık besi dönemi sonunda, kapalı sistem ve $\% 50$ yem + mera gruplarında erkek + dişi karışık cinsiyet için ortalama yemden yararlanma oranları sırasıyla; $2,26 \pm 0,03$ ve $1,61 \pm 0,03$ olarak saptanmıştır. Hindilerde yetiştirme sisteminin yemden yararlanma oranlarını etkilediği gözlenmiştir. Beyaz hindilerin 8. haftadan 17. haftanın sonuna kadar tamamen merada otlatılarak ve hiç yem verilmeden ortalama $7,5-8 \mathrm{~kg}$ ağırlığına ulaşabilmesi önemlidir. Kanatlı hayvan yetiştiriciliğinde özellikle yem giderlerinin işletme giderlerinin yaklaşık \%70 oranında büyük bir paya sahip olduğu düşünülürse mera besisi ile yem giderlerinin önemli oranda azaltılmasının önemi anlaşılacaktır. Yemden yararlanma oranı bakımından gruplar değerlendirildiğinde $\% 50$ yem + mera ve mera gruplarının kapalı sistem grubuna göre daha iyi olması, hindi yetiştiriciliğinde meraya dayalı sistemleri destekler niteliktedir. Gençkan (1997), meraya dayalı olarak yapılan kanatlı yetiştiriciliğinin yem tüketimini azaltması gibi faydalarının yanında hayvanların sağlıklı olmaları açısından büyük önem arz ettiğini bildirmiştir. Gölsüz (1984), ülkemizde her yıl 1 milyon ton tahılın, hasat kaybı ve fire olarak tarlada bırakıldığını ve atıl olarak bu artıkların değerlendirmede hindilerin önemli rol oynadığını açıklamıştır. Altan ve Koçak (1987), hindi yetiştiriciliğinde meraya dayalı sistemlerin uygun olduğunu, otlatma ve mera sistemlerinin aktif olarak uygulanmasında yem tüketiminde \%15-20 oranında yem tasarrufu sağlanabileceğini ve özellikle yem masraflarının toplam masraflar içindeki payı göz önüne alındığında, yem masraflarındaki bu düşüşün tüketiciye daha ucuz et olarak geri döneceğini bildirmişlerdir. Çakır ve ark (1981), hindilerde canlı ağırlık artışı için tüketilen yem miktarının broylerlere nazaran daha fazla olduğunu ve bu nedenle artan üretim maliyeti ile hindilerin daha pahalıya satılması durumlarının ve zorunluluğunun ortaya çıktığını, ancak hindilerin mera besisine adaptasyonlarının daha iyi olduğu ve bu özelliklerinden dolayı mera besisinin alternatif ve etkin bir şekilde uygulanabileceğini belirtmişlerdir. Camcı ve Sarıca (1991), entansif sistemde yapılan hindi besisinde yem maliyetinin toplamının toplam maliyetler içerisindeki payının \%70, palaz masrafları payının \%11-15 ve işçilik masraflarının \%6-10 arasında olduğu ancak otlatmaya dayalı besicilikte ise bu maliyetlerin önemli oranda azaldığını belirtmişlerdir.

Hindi yetiştiriciliğinde uygun mevsim ve mera koşullarında münavebeli içeri dışarı sistemlerinin tamamen mera şartlarında veya yapılan üretimin büyük oranda yem tasarrufu sağlanabileceği ve bunun yanı sıra kapalı sistemde elde edilen karkas ağırlığına yakın değerlere ulaşılabileceği görülmüştür. Bu çalışmada kapalı sistem, \%50 yem + mera ve mera gruplarının karkas verimi, yem tüketimi ve yemden yararlanma oranları incelendiğinde; erkek + dişi karışık olarak en yüksek kesim ağırlığına kapalı sistemin sahip olmasına rağmen en yüksek yem tüketiminin de kapalı sistemde olduğu, \%50 yem + mera ve mera gruplarının daha az yemle kapalı sisteme yakın canlı ağırlığa ulaştığı görülmüştür. Bu durumda hindi yetiştiriciliğinde uygun mevsim ve mera şartlarının sağlanması koşuluyla özellikle \%50 yem + mera sisteminin daha uygun olacağı söylenilebilir.

Sonuç olarak, hindi yetiştiriciliğinde tamamen kapalı sistemlerin uygun olmayacağı, uygun mevsim ve mera koşullarında tamamen mera şartlarında ya da münavebeli içeri dışarı sistemlerinin uygulanmasıyla büyük oranda yem tasarrufu sağlanabileceği görülmüştür. Bunun yanı sıra meraya dayalı yetiştiricilikte kapalı sistemlerde elde edilen karkas ağırlığına yakın değerlere ulaşılabildiği, \%50 yem + mera ve ilk sekiz haftadan sonra tamamen mera şartlarında büyütmenin karkas özellikleri ve sağlık açısından daha fazla önerilebilecektir.

\section{Kaynaklar}

Altan, Ö., Koçak, Ç., 1987. Hindiciliğin geliştirilmesi olanakları, Hayvansal Üretim Dergisi, İzmir, 26(2): 30-34.

Anonim, 1999. Hindi Yetiştiriciliği, Uluslararası Tarım ve Gıda Konfederasyonu, 2014.

Anonim, Highlights antibiotic resistance and agricultural, Animal Health Forum,

Anonim, 2006. Kanatlı verileri yıllığı, Besd-Bir, Ankara, 2006.

Anonim, 2007. Tarımsal iletmeler Genel Müdürlüğü bilgi belge merkezi (TiGEM) 2007.

Anonymous, 2004. Talking turkey, food link Local Harvest, 9(3), 2004.

Blake, I.P., 1993. Tavukçuluk artıklarının değerlendirilme yöntemleri, Uluslararası Tavukçuluk Kongresi 93, İstanbul. 106-107, 1993.

Camcı, Ö., Sarıca, M., 1991. Entansif hindi yetiştiriciliği, TiGEM Derg., Ankara, 36(6).

Cömert, N., 2004. Mısır-soya esaslı etlik erkek hindi yem karmalarına katılan avilamycin, biomoss, cylactin, yucca schidigera ekstraktının besi performansı, kesim sonuçları ile bazı kan ve bağırsak parametreleri üzerine etkileri, (Basılmamış Doktora Tezi).

Çakır, A., Haşimoğlu, S., Aksoy, A. 1981. Çiftlik hayvanlarının uygulamalı besleme ve yemlemesi, Atatürk Üniversitesi Ziraat Fakültesi Zootekni Bölümü, Erzurum. 
Ekinci, Y., 2015. Batman ili entansif koşullarında yapılan hindi yetiştiriciliğinin genel yapısı, B.Ü. Fen Bilimleri Enst. (Basılmamış Yüksek Lisans Tezi).

Eratalar, SA., 2008. Beyaz hindilerde yerleşim sıklığının performans, karkas kalitesi ve bazı stres parametrelerine etkisi, (Basılmamış Doktora Tezi).

Gençkan, SM., 1997. Tavuk ve diğer kanatlı meraları, Ege Üni. Zir. Fak., Teknik Bülten,

Gölsüz, N., 1984. Toprağın verdiğini toprağa gömüyoruz, Dört Mevsim Dergisi, 6.

Gülaç, ZN., 2011. Dünya ve Türkiye'de hindi eti, Tarımsal Ekonomi ve Politika Geliştirme Enstitüsü Yayınları/ Issn: 1303-8346 / Nüsha: 5.

Hall, S., 1996. Turkeys turned meat-machines", (www.earthsave.ca).

Işık, S., 2010. Beyaz hindi yetiştiriciliği, http: // www . angoraankara . com / kümes/ beyaz - hindi-yetiştiriciliği.

İnci, H., Taysı, R., Sevinç, EH. 2013. Bingöl ili hindi yetiştiriciliğinin mevcut durumu ve sorunları, Tr. Doğa ve Fen Derg.-Tr.J.Nature Sci., 2(1): 85-89.

Kırkpınar, F., Mert, S., 2004. Etlik hindi üretiminin temel ilkeleri, Hasad Hayvancılık Dergisi, 2(9): 24-27.

Koçak, Ç., 1984. Hindi yetiştiriciliği, T.C. Tarım ve Köy İşleri Bakanlığı Teşkilatlanma ve Destekleme Genel Müdürlüğü, Yayın No; 7, Ankara.

Konca, Y., 2001. Hindi besiciliği, Tarımsal Araştırma ve Eğitim Koordinasyonu. (TAYEK/TYUAP) 2001 Yılı Hayvancılık Grubu Bilgi Alış Veriş Toplantısı Bildirileri. Ege Tarımsal Araştırma Enstitüsü Müdürlüğü, 27-29 Mart, İzmir, Yayın No: 100, Sayfa: 21-31.

Koyubende, N., Konca, Y. 2010. Türkiye ve Avrupa Birliği'nde hindi eti üretimi, tüketimi ve politikalar, Ege Üniv. Ziraat Fak. Derg., 47(2): 201-209, İzmir.

Küçükbayrak, U., 2015. Diyarbakır ili merkez ve ilçelerinde hindi yetiştiriciliğinin yapısı ve durumu, B.Ü. Fen Bilimleri Enst. (Basılmamış Yüksek Lisans Tezi).

Nixey, CA., 1986. Comparison of growth and fat deposition of commercial avian species, 7th European Poultry Conference, Paris, 24-28.

Özkan, K., Ergül, M., 1974. Kasaplık piliç karmalarında soya küspesi yerine pamuk tohum küspesi kullanılma imkanları, Ege Üni. Zir. Fak. Dergisi. 11(1): 147-157.

Sipahi, C., 2010. Entansif hindi yetiştiriciliği işletmelerinde kârlılık ve verimlilik analizleri, Hayvan Sağlığı Ekonomisi Ve İşletmeciliği Anabilim Dalı Doktora Tezi. Türkiye
Cumhuriyeti. Ankara Üniversitesi. Sağlık Bilimleri Enstitüsü.

Tan, S., Dellal, ì., 2002. Kırmızı et üretim ve tüketim açığını kapatmak için alternatif bir yaklaşım: Hindi üretimi ve sözleşmeli yetiştiricilik modeli, Tarım Ekonomisi Araştırma Enstitüsü, $79 \mathrm{~s}$, Ankara.

Yıldırım, T., 2004. Hindi sektörü ve sektör profil araştırması, İstanbul Ticaret Odası. 